\title{
THE PATIENT'S RIGHT TO THE MEDICAL RECORD OF A THERAPEUTIC AGREEMENT IN A HUMAN RIGHTS PERSPECTIVE
}

\author{
Abdul Kolib ${ }^{\text {* }}$ \\ ${ }^{1}$ Program Doktor Ilmu Hukum, Universitas Borobudur, Indonesia \\ *Correspondence email : abdulkolib@gmail.com
}

\begin{abstract}
Health is a healthy condition, physically, mentally, spiritually and socially that enables everyone to live productively socially and economically. Health is a basic human right guaranteed in the Constitution of the Republic of Indonesia Year 1945, which with this basic right creates an obligation for anyone who organizes Health Services to fulfill that right. Health services are carried out by Health Workers which include medical workers, pharmacy workers, nursing staff, public and environmental health workers, nutrition workers, physical ignorance staff, medical technical personnel, and other health workers, one of which is a Doctor, where the legal relationship between the Doctor and the Doctor Patients are bound by an agreement called a therapeutic agreement that gives birth to the rights and obligations of both parties as the basis of the doctor in providing health services to the patient, and requires the doctor to make a document in the form of a medical record containing facts relating to the patient's health, so that in the journal This focus will be analyzing the patient's right to a medical record as well as the doctor's obligation to the patient's medical record based on human rights. This research has 2 (two) problem formulations: 1) how is the patient's right to a medical record based on human rights?; and 2) what is the doctor's obligation for the patient's medical record based on human rights? The writing of this journal was conducted using the juridical-normative legal research method, with the support of data in the form of secondary data covering legal materials, as follows: 1) primary legal material, namely the Constitution of the Republic of Indonesia Year 1945, Law No. 36 of 2009 concerning Health, Law No. 29 of 2004 concerning Medical Practices, and Regulation of the Minister of Health of the Republic of Indonesia Number 269 / MENKES / PER / III / 2008 concerning Medical Records; 2) secondary legal materials, namely literature in the form of books, scientific research, journals, etc. related to health law; and 3) tertiary legal materials which include encyclopedias, dictionaries, and so on.
\end{abstract}

Keywords: Medical Records; Patient's Right; Health Service Provider Obligations.

\section{INTRODUCTION}

Indonesia Year 1945, which with this basic right creates an obligation for anyone who organizes Health Services to fulfill that right. The definition of health based on Article 4 of Law No. 36 of 2009 concerning Health, which states 1 : "Health is a healthy state, both physically, mentally, spiritually and socially that allows everyone to live productively socially and economically." The right to health for every citizen is implied in Constitution of the Republic of Indonesia Year 1945, especially in Article $28 \mathrm{H}$ which states $^{2}$ : "every person has the right to live in physical and spiritual prosperity, to live and to have a good and healthy environment and to have health services". These rights are also guaranteed linearly in Law No. 36 of 2009 concerning Health in particular Article 4, which states: "Everyone has the right to health". 1

Regarding health services, based on Article 1 point 11 of Law No. 36 of 2009 concerning Health, which states ${ }^{1}$ : "Health efforts are any activities and / or series of 
activities carried out in an integrated, integrated and continuous manner to maintain and improve the degree of public health in the form of disease prevention, health promotion, treatment of diseases, and health recovery by government and / or community. "Health services are carried out by Health Workers based on Law No. 36 of 2009 concerning Health. The Health Workers based on Article 1 point 6 of Law no. 36 of 2009 concerning Health, which states ${ }^{1}$ : "Health workers are all people who devote themselves in the field of health and have knowledge and / or skills through education in health which for certain types require authority to conduct health efforts." The grouping of Health Workers is regulated in Elucidation of Article 21 paragraph (1) of Law No. 36 of 2009 concerning Health, which states: "Health workers can be grouped according to their expertise and qualifications, including among others medical professionals, pharmacy workers, nursing staff, community and environmental health workers, nutrition workers, physical ignorance personnel, medical technical personnel, and personnel other health." One of the Health Workers is a Doctor. ${ }^{1}$

Legal Relationships between Doctors and Patients in the health services provided by Doctors contained in the Therapeutic Agreement. A therapeutic transaction is an agreement between a doctor and a patient, in the form of a legal relationship that gives birth to rights and obligations for both parties. The object of this agreement is an effort or therapy to cure the patient. The definition of Therapeutic Agreements is a contracts made between patients with health workers and / or doctors or dentists, where health workers and / or doctors or dentists try to make the maximum effort to cure patients according to the agreement made between the two and the patient is obliged to pay the costs of healing. Where the provision of health services to patients requires doctors to make documents in the form of medical records. Medical records are facts relating to the patient's state of past and present medical history and treatment written by the health profession providing services to these patients. ${ }^{3}$ Based on this fact, the medical record which contains the fact record relating to the patient's health should absolutely belong to the patient himself, but with the existence of several related laws and regulations regarding the medical record, it is stated that the ownership of the patient's medical record is not entirely owned by the patient itself because there is other related parties are also entitled to have a medical record, so in this journal the focus will be on analyzing the patient's right to a medical record and the obligations of the health service provider for the patient's medical record based on human rights

\section{PROBLEM STATEMENT}

Formulation of the problem in this study:

1. What is the patient's right to a medical record based on Human Rights?

2. What is the doctor's obligation to a patient's medical record based on human rights?

\section{MATERIAL AND METHODS}

The writing of this journal was conducted using the juridical-normative legal research method, with the support of data in the form of secondary data covering legal materials, as follows: 1) primary legal material, namely the Constitution of the Republic of Indonesia Year $1945^{2}$, Law No. 36 of 2009 concerning Health $^{1}$, Law No. 29 of 2004 concerning Medical Practices ${ }^{4}$, and Regulation of the Minister of Health of the Republic of Indonesia Number 269 / MENKES / PER / III / 2008 concerning Medical Records5; 2) secondary legal materials, namely literature in the form of books, scientific research, journals, etc. related to health law; and 3) tertiary legal materials which include encyclopedias, dictionaries, and so on.

\section{DISCUSSION}

\section{Patient's Right to Medical Record Based on Human Rights}

According to Satijipto Raharjo, legal protection is to provide protection for human rights that have been harmed by others and that protection is given to the public so that 
they can enjoy all the rights granted by law. ${ }^{6}$ Rights have been imprinted since humans were born and are attached to anyone. Among them are the rights of independence, the right of creatures and human dignity, the right of love of others, the right of the beauty of openness and spaciousness, the right to be free from fear, the right of life, the right of spiritual, the right of conscience, the right to peace, the right to give, the right to receive, the right to protect and protect the river and so on. ${ }^{6}$ The rights to be discussed in this journal relate to the patient's right to medical records.

Medical records are evidence both for patients and for health workers in front of a court hearing, because it contains about who, when, how, the medical action took place. Thus a medical record guarantees legal certainty on the basis of justice in the context of upholding the law and providing evidence to uphold justice. ${ }^{7}$ In the Laws and Regulations specifically in the Republic of Indonesia Minister of Health Regulation No. 269 / MENKES / PER / III / 2008 concerning Medical Records, medical records are files that contain records and documents about identity, examination, treatment, actions, and other services that have been provided to patients. $^{5}$

Matters that must be included in the Medical Record include: (1) patient's identity, (2) history of illness, (3) physical examination report, (4) diagnostic and therapeutic instructions signed by an authorized doctor, (5) observational records or observation, (6) reports of actions and findings, (7) history of patients leaving health care facilities, and (8) incidents that have strayed. ${ }^{8}$ Medical records are made for orderly administration in hospitals which is one of the determining factors in the context of efforts to improve health services. ${ }^{9}$

Ownership of medical records often creates its own dilemma where on one side the medical record can belong to the patient, or to the health care provider. But based on Article 52 of Law No. 29 of 2004 concerning Medical Practices, states ${ }^{4}$ : "Patients, in receiving services in medical practice, have the right: a) to obtain a full explanation of the medical measures referred to in Article 45 paragraph (3); b) ask for the opinion of another doctor or dentist; c) get services according to medical needs; d) refuse medical treatment; and e) obtain the contents of the medical record. Legislation specifically regulating medical records is contained in Minister of Health Regulation No. 269 / MENKES / PER / III / 2008 concerning Medical Records where the ownership rights of patient medical records are regulated based on Article 12 paragraph (1) to paragraph (4) Minister of Health Regulation No. 269 / MENKES / PER / III / 2008 concerning Medical Records. ${ }^{5}$ In Article 12 paragraph (1) which states ${ }^{5}$ : "Medical record file belonging to a health service facility", and in Article 12 paragraph (2) which states: "The contents of the medical record are the property of the patient", while the contents of the medical record are in the form of a medical record summary (Article 12 paragraph (3)), where Article 12 paragraph (4) states that those entitled to obtain a summary of medical records are: a) Patients; b) The patient's family; c) The person authorized by the patient or the patient's family; and d) People who have written consent from the patient or the patient's family. Based on the aforementioned explanations, it can be seen that the medical record is still the right of the patient but is not absolutely the patient's possession where the patient is only entitled to have the contents of the medical record in the form of a summary, while the physical file of the medical record belongs to the health care facility.

\section{Doctor's Obligation to A Patient's Medical Records Based on Human Rights.}

The Legal Relationship between Doctor and Patient that creates rights and obligations that must be fulfilled by both Doctor and Patient initially occurs and is bound in an agreement called Therapeutic. Therapeutic transactions are activities in the implementation of medical practice in the form of individual health services or referred to as medical services based on their expertise and skills, and accuracy. ${ }^{10}$ Therapeutic contract is an agreement so that in the 
therapeutic contract also applies binding law which is regulated in book III BW. Thus, for the validity of the therapeutic contract, the conditions contained in Article 1320 BW must be fulfilled. ${ }^{11}$ These conditions are agreed, capable, certain things and halal reasons.

Guwandi in his book entitled "Doctors, Patients and the Law" said that, the relationship between doctors and patients is part of the civil jurisdiction which gives the parties freedom to make agreements. ${ }^{1}$ However, one thing must be kept in mind that the therapeutic engagement is not contractually "free", because the content of the therapeutic nature of the engagement is subject to positive legal / normative provisions. Forms of achievement and counter-achievement in a therapeutic engagement have been determined in such a way as in normative, ethical and medical standards. A therapeutic agreement can be said to be effective from the time a doctor declares his ability or willingness to be stated orally (implied statement) or implied statement through actions that conclude his willingness such as by accepting registration, giving the patient's serial number, recording medical records and so on. ${ }^{12}$

Regarding making medical records is an obligation of doctors who have been bound by a therapeutic agreement with the patient. The obligations are clearly stated in Article 46 and Article 47 of Law No. 29 of 2004 concerning Medical Practices, which can be described as follows:

\section{Article 46}

(1) Every doctor or dentist in carrying out medical practice must make a medical record.

(2) The medical record referred to in paragraph (1) must be completed immediately after the patient has finished receiving health services.

(3) Every medical record must be given the name, time, and signature of the officer providing the service or action.
Article 47

(1) The medical record documents as referred to in Article 46 are the property of

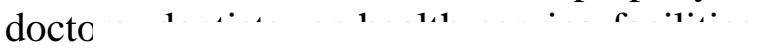
while

prope

(2) The medical record referred to in paragraph (1) must be kept and kept confidential by the doctor or dentist and the head of the health service facility.

(3) Provisions regarding medical records as referred to in paragraph (1) and paragraph (2) shall be regulated by a Ministerial Regulation.

With the obligation of the Doctor in making medical records also raises the obligation for Doctors to keep the contents of the patient's medical records confidential. According to Fred Ameln, medical secrets are: a) everything delivered by the patient (consciously or unconsciously) to the doctor, and $b$ ) everything that is known by the doctor when treating and treating patients. ${ }^{13}$ The medical secret or medical secret is also recorded in the medical record, which gives rise to the patient's right to confidentiality.

The patient's right to confidentiality is part of the moral principle of autonomy. One part of one's autonomy is to determine who is allowed to know about himself. Medical consultation can occur with the disclosure of information to a doctor, namely with the aim of treating the patient and not for other reasons. This information is the property of the patient who revealed the information and should not be given to a third person without specific consent. ${ }^{14}$

This obligation is also clearly regulated in Article 51 of Law No. 29 of 2004 concerning Medical Practices, which states ${ }^{4}$ : "Doctors or dentists in carrying out medical practices have an obligation: a) to provide medical services in accordance with professional standards and standard operating procedures and patient medical needs; b) refer the patient to another doctor or dentist who has better expertise or ability, if unable to conduct an examination or treatment; c) keep everything he knows about 
the patient, even after the patient's death; d) conduct emergency relief on the basis of humanity, except if he believes that someone else is on duty and is able to do it; and e) increase knowledge and follow developments in medicine or dentistry."

However, there are exceptions for doctors to disclose medical secrets, it is regulated in Article 48 paragraph (2) of Law no. 29 of 2004 concerning Medical Practice, which states: "medical secrets can be disclosed only for the benefit of the patient's health, fulfill the request of law enforcement officials in the context of law enforcement, patient's own request, or based on statutory provisions." 4 And Article 10 paragraph (2) Regulation of the Minister of Health of the Republic of Indonesia Number 269 / MENKES / PER / III / 2008 concerning Medical Records, which states: "Information about identity, diagnosis, history of disease, history of examination, and history of treatment can be disclosed in terms of ${ }^{5}$ :

a. for the benefit of the patient's health;

b. fulfill the request of law enforcement officials in the context of law enforcement according to a court order;

c. the request and / or the patient's own consent;

d. institutional / institutional request based on statutory provisions; and

e. for the purposes of research, education and medical audits, as long as they do not mention the patient's identity. "

Based on the two articles, that only with these reasons can medical secrets be opened, and besides the reasons stated above, doctors are not allowed to disclose medical secrets, so that doctors are obliged to keep these medical secrets.

\section{CONCLUSION}

Based on the discussion above, conclusions can be drawn on the issue of the patient's right to a medical record that the patient in receiving health services is entitled to obtain the contents of a medical record where the contents of the medical record are given to the patient in the form of a summary of the medical record, and the patient's right to a medical record is not The patient's absolute possession is entirely due to the patient's right to the medical record only in the form of the contents of the medical record, whereas the medical record file belongs to the health service facility. Then, the conclusion regarding the doctor's obligation to the patient's medical record that the doctor is obliged to make a patient's medical record where the legal relationship between the patient and the doctor is bound in a therapeutic agreement, so that in addition to the doctor's obligation to make a medical record also creates an obligation for the doctor to keep the contents of the medical record which can be called a medical secret, but the Doctor's obligation can be dropped if there are reasons as stipulated in Article 48 paragraph (2) of Law no. 29 of 2004 concerning Medical Practices and Article 10 paragraph $^{4}$ (2) Regulation of the Minister of Health of the Republic of Indonesia Number 269 / MENKES / PER / III / 2008 concerning Medical Records. ${ }^{5}$

\section{REFERENCES}

1. UU No. 36 Tahun 2009 Tentang Kesehatan.

2. Indonesia. Constitution of the Republic of Indonesia Year 1945.

3. Nasution BJ. Hukum kesehatan Pertanggungjawaban Dokter. Jakarta: Rineka Cipta; 2005.

4. UU No. 29 Tahun 2004 Tentang Praktik Kedokteran.

5. Peraturan Menteri Kesehatan No. 290/MENKES/PER/III/2008 Tentang Persetujuan Tindakan Kedokteran.

6. Rahardjo. Ilmu Hukum. Bandung: PT. Citra Aditya Bakti; 2000.

7. Indar. Etika dan Hukum Kesehatan. Makasar. Lembaga Penerbitan Unhas; 2010.

8. Ohoiwatun T. Bunga Rampai Hukum Kedokteran, Tinjauan Berbagai Peraturan Perundangan dan UU Praktek Kedokteran. Malang: Bayumedia Publishing; 2007. 
9. Rustiyanto E. Etika Profesi Perekam Medis dan Informasi Kesehatan. Yogyakarta: Graha Ilmu; 2012.

10. Komalawati V. Peranan Informed Consent Dalam Transaksi Terapeutik (Persetujuan Dalam Hubungan Dokter dan Pasien). Bandung: PT. Citra Aditya Bakti; 2002.

11. Komalawati V. Hukum dan Etika Dalam Praktik Dokter. Bandung: Pustaka Sinar Harapan; 1999.

12. Wijanarko B, Sari MP. Tinjauan Yuridis Sahnya Perjanjian Terapeutik dan Perlindungan Hukum Bagi Pasien. Priv Law. 2014;2(4):1-14.

13. Hendrik. Etika \& Hukum Kesehatan. Jakarta: Penerbit Buku Kedokteran EGC; 2014.

14. Idries, Mun'im A, Tjiptomartono AL. Penerapan Ilmu Kedokteran Forensik dalam Proses Penyidikan. Jakarta: Sagung Seto; 2008. 